Original Article

\title{
A Study on Contributing Factors of Nurses Migration to Overseas among the Staff Nurses Working In Selected Hospital at Mangalore
}

\author{
Harit Philip ${ }^{1}$, Bindhu P P ${ }^{2}$, Aswathi Babu ${ }^{3}$, Elveera Cutinha ${ }^{4}$, Jeena Joseph ${ }^{5}$, Jasmine Sarita Vas ${ }^{6}$ \\ ${ }^{1-5}$ P B BSc Nurising Nursing students, ${ }^{6}$ Assistant Professor \& Principal, Father Muller College/School of Nursing, Kankanady, \\ Mangalore.
}

Corresponding Author : Jasmine Sarita Vas, Assistant Professor, and Principal, Father Muller College/School of Nursing, Kankanady Mangalore, Mobile: 9980185843 e-mail: vasjasmine@gmail.com

$\begin{array}{ll}\text { Received } & : 15.11 .2018 \\ \text { Review Completed } & : 26.11 .2018 \\ \text { Accepted } & : 28.11 .2018\end{array}$

Keywords : Nurses, migration, contributing factors

\begin{tabular}{|c|}
\hline Access this article online \\
\hline Quick Response Code \\
\hline
\end{tabular}

\begin{abstract}
:
Nurses are the backbone of the health care sector. They have a vital role in the patient care as well as in the maintenance of standards in their profession. A significant shortage exists in India where nurses are migrating to other countries due to various reasons. This is important globally because countries with the lowest nursing and health care workforce capacities have the poorest health outcomes. Objective: To find the contributing factors for nurses migration to overseas among the staff nurses' Materials and Methods: A descriptive approach was adopted for this study. The study was conducted in Father Muller Medical College Hospital at Mangaluru. The study sample was 103 staff nurses'. A baseline proforma and a checklist were used to collect the data to assess the contributing factors of nurses' migration to overseas. The subjects were selected by using convenient random sampling technique. Results: The data in the present study revealed that, staff nurses $71.84 \%$ were between the age group of $21-25$ years. Most (88.35\%) of the subjects were females. Majorities (82.53\%) of the subjects were single. $90.30 \%$ of the subjects belong to Christian religion and rest of them belongs to Hindu religion. Proportionately (67.97\%) of the subjects who participated were had the qualification of B.Sc (N). Quiet a more number of staff Nurses' (78.64\%) was having the work experience between 13 years. The data from the checklist of contributing factors revealed that the majority $(95.14 \%)$ of them said that less salary in India is the major contributing factor for migration. The second reason given by the subjects was better employment opportunity (92.23\%). The third most reason indicated by the subject was the opportunity to improve the professional skill and practice in abroad (92.21\%). The marriage as a contributing factor to migrate was least by only (25.24\%). The next least was additional payment for extra hours (45.63\%). Interpretation and conclusion: After conducting the study the result showed that, The main contributing factors of nurses migration are less salary in India (95.14\%), Better employment opportunities in abroad (92.23\%) and the opportunity to improve the professional skill and practice in abroad (92.21\%). Also we found that there is no specific contributing factor rather they had variety of contributing factors which influences the nurses for migration.
\end{abstract}

\section{Introduction}

Oxford dictionary has stated migration as the movement of people to a new area or country in order to find out better work or living condition. In a study the term 'brain drain' is used when trained or qualified workers move from nation to another for betterment. They have also said that brain drain is also known as 'the human capital flight'. Studies have shown that in Nepal every year 250,000 youth are migrating from the country for better salary, higher living standard, education stability and security. In a report where World Health Organization suggests that migration of the health care workers has followed general trends in migration including nurses for many reasons ${ }^{1}$.In the study they have shown that shortage of nursing staff in the country which leads to increase in the international recruitment of nurses, but attention has to be directed 
toward this to retain the nurses within a country. Studies in Canada have shown that the shortage of nurses has significant effect on health care system. They have said that nurses are the important component of health care system ${ }^{2}$.Migration of the nurses globally has a major effect on the health services in many countries. It is said that nurses should take a leadership role in the research to find out the factors causing nurses for migrating to another country ${ }^{3}$. The study says that the nurses' migration is a phenomenon that has a long tradition. Florence Nightingale is known as the founding mothers of vocational nursing, which was spent in Germany to train the nurses. It is also said that shortage of registered nurses have been experienced in many countries and in times of demand nurses have been recruited from abroad. The migration of the nurses today is much serious which we cannot compare it to the past ${ }^{4}$. Globalization and worldwide shortage of registered nurses have influenced migration of nurses from developing countries to the developed countries. It is said that healthcare workers leave their home countries for better income and career opportunities, good working conditions, greater job satisfaction. A number of factors influence the nurses for migration. The migration has the major implication on the health care system ${ }^{5}$.

\section{Materials and Methods}

A descriptive design was used to conduct the study at Father Muller Medical College hospital Mangaluru, Karnataka, India from11/06/18 to $13 / 03 / 18$ consisting of 103 staff nurses.

\section{Inclusion criteria}

- Nurses who work in the selected hospital

- Nurses with more than 1 years of experience

\section{Exclusion criteria}

Staff nurses who are freshly joined

\section{Materials and Methods}

The simple random sampling was used to select the samples. The investigators administered the baseline proforma and checklist to the participants.

The baseline proforma consist of 6 items such as age, gender, marital status, religion, qualification, and work experience. The respondents were asked to fill their details. Checklist on contributing factors of nurse's migration comprised of 21 items of 'yes/no' and with ranking of most 5 priorities of contributing factors.

\section{Results}

The following table shows the demographic variables

Table 1 : frequency and parentage distribution of subjects according to base line characteristics

$n=103$

\begin{tabular}{|c|l|c|c|}
\hline SI No & Variables & Frequency & Percentage \\
\hline 1 & Age in years & 74 & 71.84 \\
& b) 21-25years & 20 & 19.42 \\
& c) 26-30 years & 9 & 8.74 \\
\hline 2 & d) 31 and above & & \\
& Gender & 12 & 11.65 \\
& a) male & 91 & 88.35 \\
\hline 3 & b) female & & \\
& Marital status & 85 & 82.53 \\
& a) single & 18 & 17.47 \\
\hline 4 & b) married & Religion & \\
& a) Hindu & 10 & 9.70 \\
& b) Christian & 93 & 90.30 \\
\hline 5 & Highest qualification in nursing & & \\
& a) Diploma in nursing & 33 & 32.03 \\
& b) Bachelors in nursing & 70 & 67.97 \\
\hline 6 & Work experience & & \\
& a) 1year to 3 year & 81 & 78.64 \\
& b) 4year to 6year & 13 & 12.63 \\
& c) 7year to 9year & 4 & 3.88 \\
& d)10years to above & 5 & 4.85 \\
\hline
\end{tabular}

Table 2: Frequency and percentage of contributing factors of nurses' migration

$n=103$

\begin{tabular}{|c|l|lr|c|}
\hline SI.No & lontributing Factors & \multicolumn{2}{|l|}{ Frequency } & Percentage \\
\hline 1 & Better employment & YES & 95 & 92.23 \\
& opportunities & NO & 8 & 7.76 \\
\hline 2 & Marriage & YES & 26 & 25.24 \\
& & NO & 77 & 74.75 \\
\hline \multirow{2}{*}{3} & \multirow{2}{*}{ Better social status } & YES & 84 & 81.55 \\
& & NO & 19 & 18.44 \\
\hline \multirow{2}{*}{4} & \multirow{2}{*}{ Scope for higher education } & YES & 89 & 86.40 \\
& & NO & 14 & 13.59 \\
\hline 5 & \multirow{2}{*}{ Better life style } & YES & 90 & 87.37 \\
& & NO & 13 & 12.62 \\
\hline 6 & Society does not look & YES & 64 & 62.13 \\
& optimistically towards nurses & NO & 39 & 37.86 \\
\hline 7 & Children's future & YES & 78 & 75.72 \\
& & NO & 25 & 24.27 \\
\hline
\end{tabular}




\begin{tabular}{|c|c|c|c|c|}
\hline \multirow{2}{*}{$\frac{\text { SI.No }}{8}$} & \multirow{3}{*}{\begin{tabular}{|l|} 
Contributing Factors \\
Encouragements of family \\
members/relatives
\end{tabular}} & \multicolumn{2}{|c|}{ Frequency } & \multirow{2}{*}{\begin{tabular}{|c} 
Percentage \\
86.40
\end{tabular}} \\
\hline & & YES & 89 & \\
\hline & & NO & 14 & 13.59 \\
\hline \multirow[t]{2}{*}{9} & More Opportunity for & YES & 84 & 81.55 \\
\hline & Government sector & NO & 19 & 18.44 \\
\hline \multirow[t]{2}{*}{10} & Flexible working hours & YES & 87 & 84.46 \\
\hline & & NO & 16 & 15.53 \\
\hline \multirow[t]{2}{*}{11} & Dissatisfaction of job status & YES & 70 & 67.96 \\
\hline & & NO & 33 & 32.03 \\
\hline \multirow[t]{2}{*}{12} & Less salary & YES & 98 & 95.14 \\
\hline & & NO & 5 & 4.85 \\
\hline \multirow[t]{2}{*}{13} & Nurses scope is quite less & YES & 77 & 74.75 \\
\hline & & NO & 26 & 25.24 \\
\hline \multirow[t]{2}{*}{14} & Status of nurses is high & YES & 90 & 87.37 \\
\hline & & NO & 13 & 12.62 \\
\hline \multirow[t]{2}{*}{15} & Equal rights of citizenship & YES & 70 & 70.87 \\
\hline & & NO & 30 & 29.12 \\
\hline \multirow[t]{2}{*}{16} & Job security & YES & 52 & 50.48 \\
\hline & & NO & 51 & 49.51 \\
\hline \multirow[t]{2}{*}{17} & Better payment for extra hours & YES & 47 & 45.63 \\
\hline & & NO & 56 & 54.36 \\
\hline \multirow[t]{2}{*}{18} & Maximum opportunity in policy & YES & 66 & 64.07 \\
\hline & making and implementation & NO & 37 & 35.92 \\
\hline \multirow[t]{2}{*}{19} & Safe social environment & YES & 72 & 69.90 \\
\hline & & NO & 31 & 30.09 \\
\hline \multirow[t]{3}{*}{20} & Opportunities to improve the & YES & 95 & 92.21 \\
\hline & professional skills and practice & NO & 8 & 7.76 \\
\hline & & NO & 103 & 100.00 \\
\hline
\end{tabular}

Table 3 : showing the frequency and percentage of ranking of contributing factors

$\mathrm{n}=103$

\begin{tabular}{|c|c|c|c|c|}
\hline SI. No & Contributing Factors & Frequenc & ercentag & e Ranking \\
\hline 1 & Less salary & 74 & 71.82 & $1^{\text {st }}$ rank \\
\hline 2 & $\begin{array}{l}\text { Better employment } \\
\text { opportunity }\end{array}$ & 57 & 55.31 & $2^{\text {nd }}$ rank \\
\hline 3 & Better life style & 53 & 51.53 & $3^{\text {rd }}$ rank \\
\hline 4 & Flexible working hours & 42 & 40.85 & $4^{\text {th }}$ rank \\
\hline 5 & Job security & 38 & 36.87 & $5^{\text {th }}$ rank \\
\hline 6 & $\begin{array}{l}\text { Scope for higher } \\
\text { education }\end{array}$ & 34 & 32.98 & $6^{\text {th }}$ rank \\
\hline 7 & Better social status & 33 & 32.01 & $7^{\text {th }}$ rank \\
\hline 8 & $\begin{array}{l}\text { Better payment for } \\
\text { extra hours }\end{array}$ & 31 & 30.07 & $8^{\text {th }}$ rank \\
\hline 9 & Marriage & 26 & 25.22 & $9^{\text {th }}$ rank \\
\hline 10 & Status of nurses is high & 24 & 23.28 & $10^{\text {th }}$ rank \\
\hline 11 & Children's future & 20 & 19.04 & $11^{\text {th }}$ rank \\
\hline 12 & $\begin{array}{l}\text { Encouragement of } \\
\text { family or relatives }\end{array}$ & 14 & 13.58 & $12^{\text {th }}$ rank \\
\hline 13 & $\begin{array}{l}\text { More opportunity for } \\
\text { government sector }\end{array}$ & 12 & 11.64 & $13^{\text {th }}$ rank \\
\hline 14 & $\begin{array}{l}\text { Equal rights of } \\
\text { citizenship }\end{array}$ & 11 & 10.67 & $14^{\text {th }}$ rank \\
\hline 15 & Dissatisfaction of job & 8 & 7.76 & $15^{\text {th }} \mathrm{rank}$ \\
\hline
\end{tabular}

\begin{tabular}{|c|l|c|c|c|}
\hline SI. No & Contributing Factors & Frequency & Percentage & Ranking \\
\hline 16 & $\begin{array}{l}\text { Opportunities to } \\
\text { improve the professional } \\
\text { skill and practice }\end{array}$ & 8 & 7.76 & $16^{\text {th }}$ rank \\
\hline 17 & $\begin{array}{l}\text { Society does not look } \\
\text { optimistically towards } \\
\text { nurses }\end{array}$ & 7 & 6.79 & $17^{\text {th }}$ rank \\
\hline 18 & Nurses scope is quite less & 5 & 4.85 & $18^{\text {th }}$ rank \\
\hline 16 & $\begin{array}{l}\text { Opportunities to } \\
\text { improve the professional } \\
\text { skill and practice }\end{array}$ & 8 & 7.76 & $16^{\text {th }}$ rank \\
\hline 17 & $\begin{array}{l}\text { Society does not look } \\
\text { optimistically towards } \\
\text { nurses }\end{array}$ & 7 & 6.79 & $17^{\text {th }}$ rank \\
\hline 18 & Nurses scope is quite less & 5 & 4.85 & $18^{\text {th }}$ rank \\
\hline 19 & Safe social environment & 4 & 3.88 & $19^{\text {th }}$ rank \\
\hline 20 & $\begin{array}{l}\text { Maximum opportunity in } \\
\text { policy making and }\end{array}$ & 1 & 0.97 & $20^{\text {th }}$ rank \\
implementation & &
\end{tabular}

\section{Discussion}

\section{Major findings of the study}

\section{Section I: Description of baseline characteristics.}

- The data in the present study revealed that staff nurses $71.84 \%$ were between the age group of $21-25$ years

- Most(88.35\%) of the subjects were females

- Majority (82.53\%) of the subjects were single

- Majority(90.30\%) of the subjects belong to Christian religion and rest of them belong to Hindu religion

- Majority (67.97\%)of the subjects who participated were B.Sc

- Most (78.64\%) of the subjects were having the work experience between 1-3 years

A descriptive study was conducted in Ludhiana, Punjab, to assess the factors intended to migration among nurses. The study revealed that Out of 100, maximum (94) of the subjects were females and only 6 were male. About $79 \%$ of staff nurses were in age group 20-30 years, and 65 were unmarried whereas 34 were married. Regarding education, 71 staff nurses were GNM, 21 were B. Sc. Nurses and very few post Basic B. Sc. Nurses and only one was $M$. Sc. Nurse. As per years of experience, $38 \%$ were having $<1$ year of experience, $35 \%$ had $1-5$ years, $14 \%$ had $5-10$ years and $13 \%$ were having $>10$ years of experience ${ }^{4}$. 
Section II: Finding the contributing factors of nurses migration.

- Out of 20 contributing factors the majority (95.14\%) of them said that less salary in India is the major contributing factor for migration.

- The second reason given by the subject is better employment opportunity (92.23\%).

- The third most reason indicated by the subject is opportunity to improve the professional skill and practice in abroad (92.21\%).

- The marriage as a contributing factor to migrate was least by only (25.24\%). And the next least was additional payment for extra hours (45.63\%).

Another descriptive study which was conducted in Gujarat among staff nurses which revealed that out of 200 staff majority (94\%) samples were encouraged to migrate for the higher status in foreign country than India. And about $91 \%$ of samples migrated for the better salary. About $88 \%$ of the subjects encouraged for better employment opportunity. And $76.5 \%$ samples got motivated to migrate due to society's negative attitude towards nurses ${ }^{5}$.

\section{Section III: Ranking of contributing factors according the priorities}

The subjects were asked to note down the (5) contributing

References

1. Baral R, Sapkota S. Factors influencing migration among Nepalese nurses. Journal of Chitwan Medical College. 2015;5(2):25-9. Available from https://www.nepjol.info/index.php/JCMC/article/view/13151

2. Hall LM, Gates M, Peterson J, Jones C, Pink GH. Waiting and watching: Nurse migration trends before a change to the National Council Licensure Examination as entry to practice for Canada's nurses. Nursing outlook. 2014 Jan 1;62(1):53-8. Available from- https://www. ncbi.nlm.nih.gov/pubmed/24345616

3. Freeman M, Baumann A, Fisher A, Blythe J, Akhtar-Danesh N. Case study methodology in nurse migration research: An integrative review. Applied Nursing Research. 2012 Aug 1;25(3):222-8.Available fromhttps://www.sciencedirect.com/science/article/pii/S089718971200 0043

4. Habermann M, Stagge M. Nurse migration: a challenge for the profession and health-care systems. Journal of Public Health. 2010 Feb 1;18(1):43-51. Available from-https://link.springer.com/article /10.1007/s10389-009-0279-0

5. Walani SR. Global migration of internationally educated nurses: experiences of employment discrimination. International Journal of Africa Nursing Sciences. 2015 Jan 1;3:65-70. Available fromhttps://www.sciencedirect.com/science/article/pii/S221413911500 0220 factors which they feel is the most influence in migration of the nurses.

- Out of 103 subjects $71.82 \%$ (74 subjects) felt that low salary is the main reason for migration.

- Better employment opportunity ranked as $2^{\text {nd }}(55.31 \%)$ reason and better life style $(51.53 \%)$ stood as $3^{\text {rd }}$ most reason for the migration.

The descriptive study which was conducted in Ludhiana, Punjab among staff nurses and found out the rank order of professional factor was high in better job opportunities and professional improvement ( $\operatorname{rank} 1^{\text {st }}$ ) and lowest in retention of nurses $\left(\right.$ rank $\left.10^{\text {th }}\right)$. Among economical factors, rank order of economical factor (rank $1^{\text {st }}$ ) and lowest in benefit packages and financial constraints (rank $3^{\text {rd }}$ ). In personal factors, rank order was high in better lifestyle (rank $1^{\text {st }}$ ) and lowest in better family relation (rank $8^{\text {th }}$ ) among staff nurses. Among psychological factors, rank order was high in dignified job (rank $1^{\text {st }}$ ) and lowest in less workload (rank $\left.3^{\text {rd }}\right)$.

\section{Discussion}

The findings of this study and other studies show that there is no specific contributing factor rather there are variety of contributing factors which influences the nurses for migration. 